\title{
ANALISIS PERLAKUAN AKUNTANSI PIUTANG DI PT. SUCOFINDO (PERSERO) CABANG JAKARTA
}

\author{
Aprilia V. Manuel ${ }^{1}$, Hendrik Manossoh $^{2}$, Dhullo Affandi ${ }^{3}$ \\ ${ }^{1,2,3}$ Fakultas Ekonomi dan Bisnis, Jurusan Akuntansi, Universitas Sam Ratulangi, Jl. Kampus Bahu, Manado, \\ 95115, Indonesia \\ E-mail : Aprilia.v.manuel@gmail.com
}

\begin{abstract}
The company basically runs its business through the sale of goods or services every day that will generate revenue for the company. Receivables are considered very important because it is one component in the balance sheet, so accuracy in processing receivables greatly affect the fairness of its valuation in the financial statements. And the appropriate Financial Accounting Standards are very important in presenting the financial statements because accounting standards provide information to users of financial statements regarding the financial position, results of operations, and other matters relating to the company. The purpose of this study is to analyze the suitability of accounting treatment of PT. SUCOFINDO (Persero) Jakarta branch with the applicable financial accounting standards and formulate accounting standards for receivables that must be used by PT. SUCOFINDO (Persero) Jakarta branch. This research was conducted by qualitative descriptive method. The results of this study show that the accounting treatment of PT. SUCOFINDO (Persero) Jakarta Branch is not in accordance with the applicable financial accounting standards because the presentation of receivables in the financial statements is presented in the net amount, and the recording of receivables written-off is written off into other income accounts. As a suggestion that PT. SUCOFINDO (Persero) represents accounts receivable in the statement of financial position with gross amount followed by estimated uncollectible amounts, and returns the receivables written off to accounts receivable and allowance for doubtful accounts and cash accounts and accounts receivable as deductions on receivables so that the presentation of accounts receivable in accordance with applicable financial accounting standards.
\end{abstract}

Keywords : Accounting treatment of receivables, Statement of Financial Accounting Standards

\section{PENDAHULUAN}

Perusahaan menjalankan usahanya melalui transaksi penjualan barang atau jasa setiap harinya. Penjualan barang atau jasa itulah yang nantinya akan menghasilkan pendapatan bagi perusahaan. Oleh sebab itu, penjualan yang lancar akan menyebabkan lancarnya arus kas masuk bagi perusahaan. Setiap perusahaan mempunyai aktiva untuk mendukung kegiatan usahanya. Aktiva adalah sumber-sumber ekonomi yang dimiliki perusahaan dan yang bisa dinyatakan dalam satuan uang (Haryono 2012:28). Aktiva itu dibagi menjadi dua yaitu aktiva lancar dan aktiva tetap. Aktiva tetap dibagi menjadi aktiva tetap berwujud dan aktiva tetap tidak berwujud. Sedangkan aktiva lancar merupakan aktiva dimana dana yang tertanam didalamnya akan bebas dalam jangka waktu pendek. Fahmi (2013:31) menyatakan aktiva lancar adalah aktiva yang memiliki tingkat perputaran yang tinggi dan paling cepat bisa dijadikan uang tunai, dengan penetapan periode waktu tertentu 1 (satu) tahun.

Penjualan secara tunai tidak akan menyebabkan masalah yang signifikan bagi perusahaan, sedangkan penjualan secara kredit akan menimbulkan piutang dan timbulnya resiko pembayaran bagi perusahaan. Piutang merupakan suatu proses yang penting, yang 
dapat menunjukkan satu bagian yang besar dari harta likuid perusahaan. Piutang merupakan salah satu bagian terpenting dari modal kerja (Mihajlov, 2011). Piutang dinilai sangat penting karena merupakan salah satu komponen dalam neraca, sehingga ketelitian dalam pengolahan piutang sangat berpengaruh terhadap kewajaran penilaiannya dalam laporan keuangan. Akuntansi yang tepat atas piutang usaha dapat berpengaruh penting pada laporan keuangan. Dan standar akuntansi keuangan yang tepat sangat penting dalam menyajikan laporan keuangan karena standar akuntansi memberikan informasi kepada pemakai laporan keuangan tentang posisi keuangan, hasil usaha, dan hal-hal lain yang berkaitan dengan perusahaan. Jika perlakuan akuntansi piutang usaha berpedoman pada Standar Akuntansi Keuangan piutang usaha yang tepat, maka laporan keuangan akan mencerminkan suatu penilaian yang wajar.

PT. SUCOFINDO (Persero) adalah perusahaan patungan antara Pemerintah Republik Indonesia dengan Societe Generate de Surveillance Holding SA (SGS), Genewa Swiss yang merupakan perusahaan inspeksi pertama di Indonesia. Bergerak di bidang jasa inspeksi, pengkajian \& pengujian, pelatihan \& konsultasi dan memiliki cabang dihamper seluruh wilayah Indonesia. Salah satu cabang PT. SUCOFINDO (Persero) terletak di Kota Jakarta. PT. SUCOFINDO (Persero) cabang Jakarta juga dalam pelayanan kepada pelanggan memberikan pelayanan jasa secara kredit. PT. SUCOFINDO (Persero) cabang Jakarta mengalami ketidaksesuaian perlakuan akuntansi pada saat terjadinya pembayaran kembali piutang yang telah dihapuskan dan penyajian jumlah piutang dalam laporan posisi keuangan. Untuk pencatatan pembayaran kembali piutang yang telah dihapuskan, PT. SUCOFINDO (Persero) cabang Jakarta mencatat sebagai pendapatan lain-lain. Dan untuk penyajian piutang dalam laporan posisi keuangan, PT. SUCOFINDO (Persero) cabang Jakarta menyajikannya dalam jumlah bersih setelah penyisihan.

PT. SUCOFINDO (Persero) cabang Jakarta, yang banyak melakukan kegiatan sehariharinya melalui transaksi-transaksi bisnis, sangat perlu untuk menangani piutang-piutangnya agar terkelola dengan baik dan sesuai dengan Standar Akuntansi Keuangan yang berlaku, khusunya untuk akun piutang usaha. Oleh karena itu, pengendalian terhadap perlakuan akuntansi piutang pada PT. SUCOFINDO (Persero) diharapkan dapat menghasilkan informasi mengenai piutang usaha yang akurat, handal dan relevan untuk pengambilan keputusan bagi pihak manajemen perusahaan serta dapat menjaga aset perusahaan terutama pada piutang usaha. Karena melihat betapa pentingnya perlakuan akuntansi piutang di setiap perusahaan terutama perusahaan yang melakukan penjualan secara kredit, maka memungkinkan penulis untuk menganalisis perlakuan akuntansi piutang perusahaan ini apakah perlakuan akuntansi piutang usaha sudah tepat dan sesuai dengan Standar Akuntansi Keuangan. Berdasarkan uraian diatas maka penulis ingin mengetahui bagaimana prosedur pengelolaan piutang yang diterapkan oleh PT. SUCOFINDO (Persero) cabang Jakarta mulai dari terjadinya penjualan kredit, pencatatan akuntansi piutang sampai dengan penyisihan dan penghapusbukuan piutang dengan mengangkat judul "Analisis Perlakuan Akuntansi Piutang Di PT. SUCOFINDO (Persero) Cabang Jakarta." Adapun tujuan yang ingin dicapai dalam penelitian ini adalah untuk menganalisis kesesuaian perlakuan akuntansi piutang PT. SUCOFINDO (Persero) cabang Jakarta dengan Standar Akuntansi Keuangan yang berlaku dan untuk merumuskan standar akuntansi piutang yang seharusnya digunakan oleh PT. SUCOFINDO (Persero) cabang Jakarta.

\section{TINJAUAN PUSTAKA}

\subsection{Akuntansi}

Akuntansi adalah informasi yang menjelaskan kinerja keuangan entitas dalam suatu periode tertentu dan kondisi keuangan entitas pada tanggal tertentu (Martani 2012:4). Pontoh (2013:1) menyatakan akuntansi sering disebut sebagai bahasa bisnis. Akuntansi adalah bahasa bisnis dan seni yang meliputi pencatatan, penggolongan, pengikhtisaran dan penyajian 
laporan mengenai transaksi keuangan yang terjadi dalam perusahaan (Wati, Yeyen Herlina, dkk. 2013). Akuntansi menghasilkan informasi yang menjelaskan kinerja keuangan entitas dalam suatu periode tertentu dan kondisi keuangan entitas pada tanggal tertentu. Informasi keuangan tersebut digunakan oleh para pemakai agar dapat membantu dalam membuat prediksi kinerja dimasa mendatang.

\subsection{Akuntansi Keuangan}

Akuntansi keuangan membahas penyususnan laporan keuangan untuk tujuan pengguna eksternal. Martani (2012:8) menyatakan akuntansi keuangan berorientasi pada pelaporan pihak eksternal. Beragamnya pihak eksternal dengan tujuan spesifikasi bagi masing-masing pihak membuat pihak penyusun laporan keuangan menggunakan prinsip dan asumsi-asumsi dalam penyusunan laporan keuangan. Untuk itu diperlukan standar akuntansi yang dijadikan pedoman baik oleh penyusun maupun pembaca laporan keuangan. Laporan yang dihasilkan dari akuntansi keuangan berupa laporan keuangan untuk tujuan umum (generali purpose financial statement).

\subsection{Piutang}

\subsubsection{Definisi Piutang}

Piutang merupakan salah satu dari bentuk asset lancar yang dimiliki suatu entitas. Piutang merupakan asset likuid dalam suatu perusahaan (Novi, 2009). piutang merupakan aset lancar yang dijual, dikonsumsi atau direalisasikan sebagai bagian siklus operasi normal meskipun aset tersebut tidak diperkirakan untuk direalisasikan dalam jangka waktu dua belas bulan setelah periode pelaporan (PSAK No.1 revisi 2015).

\subsubsection{Klasifikasi Piutang}

Penggolonga piutang menurut Standar Akuntansi Keuangan (2013) yaitu menurut sumber terjadinya, ialah piutang usaha dan piutang lain-lain. Sedangkan pengklasifikasian bisa berupa dengan beberapa cara : (1) piutang terdiri dari piutang usaha (trade receivable) dan piutang non usaha (non-trade receivable), (2) piutang terdiri dari piutang yang bersifat lancar atau jangka pendek, dan piutang tidak lancar atau jangka panjang.

\subsection{Pendapatan}

Di Indonesia, pengaturan mengenai akun penghasilan diatur dalam Pernyataan Standar Akuntansi Keuangan (PSAK) No. 23. Menurut PSAK No. 23 (revisi 2014) penghasilan didefinisikan dalam Kerangka Dasar Penyusunan dan Penyajian Laporan Keuangan sebagai kenaikan manfaat ekonomi selama suatu periode akuntansi dalam bentuk pemasukan atau penambahan aset, atau penurunan liabilitas yang mengakibatkan kenaikan ekuitas yang tidak berasal dari konstribusi penanaman modal.

Penghasilan dapat berupa pendapatan (revenue) maupun keuntungan (gain). Pendapatan adalah arus masuk bruto dari manfaat ekonomi yang timbul dari aktivitas normal entitas selama suatu periode jika arus masuk tersebut mengakibatkan kenaikan ekuitas yang tidak berasal dari kontribusi penanaman modal dan dikenal dengan sebutan yang berbedabeda, seperti penjualan, penghasilan jasa, bunga, deviden, royalti, dan sewa.

\subsection{Perlakuan Akuntansi Piutang Usaha \\ 2.5.1 Pengakuan Piutang Usaha}

Pengakuan piutang sering berhubungan dengan pengakuan pendapatan. Karena pengakuan pendapatan pada umumnya dicatat ketika proses menghasilkan laba telah selesai dan kas terealisasi atau dapat direalisasi, maka piutang yang berasal dari penjualan barang umumnya diakui pada waktu hak milik atas barang beralih ke pembeli, sedangkan penjualan jasa umumnya diakui pada saat penyerahan jasa atau jasa itu dilaksanakan. Menurut PSAK 
No. 23 (revisi 2014) menyatakan bahwa pendapatan atas transaksi penjualan jasa diakui dengan acuan pada tingkat penyelesaian dari transaksi pada tanggal neraca.

\subsubsection{Pengukuran Piutang Usaha}

Pengukuran piutang mencakup kapan diakui dan berapa jumlah piutang dan harus dicatat agar jumlah yang disajikan menunjukan nilai yang wajar. Pengukuran piutang dilakukan terhadap piutang usaha dan piutang wesel, karena keduanya sering dijumpai dalam suatu perusahaan dan biasanya meliputi jumlah yang besar. Dengan adanya pengukuran piutang tersebut maka dapat diketahui dengan tepat nilai wajar piutang yang bersangkutan. Sesuai PSAK No. 55 (revisi 2014) aset keuangan diukur nilai wajar bagi yang diakui. Nilai wajar sebagai harga yang akan diterima atau harga yang akan dibayar (PSAK No. 68, revisi 2014). Secara teori, semua piutang diukur dalam jumlah yang mewakili nilai sekarang dari perkiraan penerimaan kas di masa datang. Oleh karena itu, piutang usaha berjangka pendek.

\subsubsection{Pencatatan Piutang Usaha}

Piutang sering dicatatat di neraca perusahaan saat menjual barang atau jasa dilakukan secara kredit (Gorondutse, dkk, 2016). Menurut PSAK No 1 (revisi 2015), entitas menyusun laporan keuangan atas dasar akrual, kecuali laporan arus kas. Sehingga pencatatan yang dilakukan sebaiknnya menggunakan metode akuntansi berbasis akrual (accrual basic). Prosedur pencatatan piutang terdiri pengakuan piutang, penerimaan piutang, pencatatan piutang ragu-ragu, pencatatan penyisihan piutang, dan penerimaan kembali piutang yang telah dihapuskan. Prosedur pencatatan piutang bertujuan untuk mencatat mutasi piutang perusahaan kepada setiap debitur.

\subsubsection{Penyajian dan Pengungkapan piutang usaha}

Menurut PSAK No. 9 piutang diklasifikasikan sebagai aktiva lancar. Piutang dinyatakan sebesar jumlah kotor tagihan dikurangi dengan taksiran jumlah yang tidak dapat ditagih. Jumlah kotor piutang harus tetap disajikan pada neraca diikuti dengan penyisihan untuk piutang yang diragukan atau taksiran jumlah yang tidak dapat ditagih. Pada akhir periode akuntansi, perusahaan akan menyusun laporan keuangan. Piutang merupakan salah satu unsur yang cukup material dari aktiva lancar sehingga pengungkapannya pada neraca harus dilakukan secara tepat dan jelas agar tidak menyesatkan para pemakai laporan keuangan.

\subsection{Penelitian Terdahulu}

Penelitian terdahulu ini menjadi salah satu acuan peneliti dalam melakukan penelitian sehingga peneliti dapat memperkaya teori yang dapat digunakan dalam mengkaji penelitian yang dilakukan peneliti yaitu:

Shinta Wahyu Hati \& Yulia Nababan (2013) yang berjudul perlakuan akuntansi terhadap piutang pada Unit Bisnis Infrastruktur PT PLN Batam menunjukkan bahwa pertama, pengakuan piutang yang dilakukan Unit Bisnis Infrastruktur PT PLN Batam belum sesuai dengan Prinsip Akuntansi Berlaku Umum (PABU). Unit Bisnis Infrastruktur PT PLN Batam hanya mengakui penggunaan tiang listrik pada saat pelunasan saja. Kedua, Pencatatan akuntansi terhadap piutang pada Unit Bisnis Infrastruktur PT PLN Batam belum sesuai dengan Prinsip Akuntansi Berterima Umum. Unit Bisnis Infrastruktur PT PLN Batam tidak melakukan pencatatan jurnal pada saat piutang terjadi. Ketiga, Unit Bisnis Infrastruktur PT PLN belum melakukan pencatatan berupa jurnal yang dibutuhkan dalam pengakuan, pencatatan dan penilaian.

Sri Rahayu (2013) yang berjudul Analisis perlakuan akuntansi atas piutang dagang pada Apotek Rakyat Langkat menunjukan bahwa pertama, Apotek Rakyat Langkat belum 
menerapkan perlakuan akuntansi yang benar terhadap piutang dagangnya. Kedua, Apotek Rakyat Langkat belum menyusun laporan keuangan yang sesuai dengan SAK sehingga penyajian piutang dan cadangan kerugian piutang tidak dapat diketahui.

Andhika Adhi Putranto (2009) yang berjudul analisis perlakuan akuntansi atas piutang usaha pada PT. Hasuda Graha menunjukan bahwa Pencatatan akuntansi atas pengakuan dan pelunasan piutang usaha yang dilakukan oleh PT. Hasuda Graha sudah mengacu pada Standar akuntansi keuangan yang berlaku. Penyajian piutang usaha pada neraca sudah sesuai dengan stanar akuntansi yang berlaku, yakni disajikan sesuai dengan nilai bersih yang dapat direalisasi (net realizable value). PT. Hansu Graha tidak melakukan perhitungan estimasi piutang tak tertagih.

\section{METODE PENELITIAN}

\subsection{Jenis dan sumber data}

Dalam penelitian ini, jenis data yang digunakan yaitu data kualitatif dan data kuantitatif. Data kualitatif adalah data yang tidak dapat diukur dalam skala numerik atau data dalam bentuk kata - kata yaitu data yang diperoleh melalui wawancara dan dokumentasi. Dan data kuantitatif adalah data yang diukur dalam suatu skala numerik (angka). Sedangkan sumber data yang digunakan yaitu data primer dan data sekunder. Data primer merupakan sumber data yang langsung memberikan data kepada pengumpul data (Sugiyono, 2012:137) atau data yang diperoleh secara langsung dari perusahaan berupa data mentah yang perlu diolah lagi. Dan data sekunder merupakan sumber data yang tidak langsung memberikan data kepada pengumpul data, misalnya lewat orang lain atau dokumen (Sugiyono, 2012 :137).

\subsection{Metode analisis}

Dalam penelitian ini, analisis data menggunakan metode kualitatif yang dimulai dari pengelolaan data, penguraian hasil penelitian secara deskriptif dan menarik kesimpulan yang bersifat kualitatif berdasarkan perbandingan antara fakta yang ada di perusahaan dengan standar akuntansi keuangan yang berlaku. Dalam menganalisis beberapa masalah, penulis menggunakan cara berfikir deduktif atau cara berfikir yang memulai dari pengetahuan yang bersifat umum dan bertitik tolak dari pengetahuan umum untuk menilai suatu kejadian khusus yang berhubungan dengan perlakuan akuntansi piutang di PT. SUCOFINDO (Persero) cabang Jakarta.

\section{HASIL PENELITIAN DAN PEMBAHASAN}

\subsection{Hasil Penelitian}

\section{Perlakuan Akuntansi Piutang}

Dari hasil penelitian perlakuan akuntansi piutang terdiri dari:

1. Pengakuan piutang

2. Pengukuran piutang

3. Pencatatan piutang

4. Penyajian dan pengungkapan piutang

\subsection{Pembahasan}

\subsubsection{Analisis Pengakuan Piutang PT. SUCOFINDO (Persero)}

Pengakuan piutang erat kaitannya dengan pengakuan pendapatan, dimana pendapatan pada umumnya diakui dan dicatat ketika proses menghasilkan laba telah selesai dan terealisasi. Dasar pengakuan piutang perusahaan menggunakan dasar realisasi, dimana piutang diakui setelah jasa selesai diberikan dan telah diterbitkan invoice, seperti pada tanggal 17 Februari 2014 perusahaan mengakui piutang sebesar Rp. 11.500.000,-, pada 
tanggal 8 Juni 2015 sebesar Rp. 12.000.000,-, dan pada tanggal 1 Maret 2016 perusahaan mengakui piutang sebesar Rp. 10.750.000,-.

Secara umum berdasarkan ketiga transaksi tersebut, perusahaan telah mengakui piutang sesuai dengan Standar Akuntansi Keuangan yang berlaku yaitu PSAK No. 23 (revisi 2014) yang menyatakan bahwa pendapatan sehubungan dengan transaksi penjualan jasa harus diakui dengan acuan pada tingkat penyelesaian dari transaksi pada tanggal transaksi. Karena sehubungan dengan transaksi diatas, piutang yang berasal dari penjualan jasa umumnya diakui pada saat jasa itu dilaksanakan dan diakui berdasarkan nilai tukar dari aset yang dijual antara pihak yang melakukan transaksi. Dimana nilai tukar ini adalah nilai yang akan dibayarkan oleh debitur pada saat yang telah ditentukan dan dibuktikan oleh bukti berupa dokumen yang disebut dengan faktur. Dengan demikian, dalam hal pengakuan piutang PT. SUCOFINDO (Persero) cabang Jakarta telah mengakui piutang sesuai dengan Standar Akuntansi Keuangan yang berlaku.

\subsubsection{Analisis Pengukuran Piutang PT. SUCOFINDO (Persero)}

Pengukuran piutang mencakup kapan diakui dan berapa jumlah piutang yang harus dicatat agar jumlah yang disajikan menunjukan nilai yang wajar. Dengan adanya pengukuran piutang, maka dapat diketahui dengan tepat nilai wajar piutang. Pada PT. SUCOFINDO (Persero) cabang Jakarta, piutang diukur sebesar nilai wajar atau sebesar jumlah yang dapat direalisasikan dan dapat diterima dalam bentuk kas. Dimana jumlah piutang yang diakui sebesar harga pertukaran (exchange price) atau kesepakatan antara pihak perusahaan dengan pelanggan. Transaksi pada tanggal 17 Februari jumlah yang diakui sebesar Rp. 11.500.000,-, pada tanggal 8 Juni 2015 jumlah piutang yang diakui sebesar Rp. 12.000.000,-, dan pada tanggal 1 Maret 2016 jumlah yang diakui sebesar Rp. 10.750.000,-.

Kemudian untuk menentukan nilai realisasi bersih, PT. SUCOFINDO (Persero) cabang Jakarta mengestimasikan piutang tak tertagih dengan menggunakan metode penyisihan atau cadangan. Dimana pada akhir periode pelaporan (tahunan), perusahaan menentukan besarnya taksiran piutang tak tertagih yang nantinya akan diakui dan dilaporkan sebagai kerugian piutang pada periode berjalan.

Jumlah piutang untuk periode tahun 2014 yang dilaporkan perusahaan dalam laporan posisi keuangan sebesar Rp. 23.353.000,- yang merupakan jumlah setelah penyisihan piutang tak tertagih. Kemudian pada periode 2015, jumlah piutang yang dilaporkan perusahaan sebesar Rp. 18.506.000,-. Jumlah ini juga merupakan jumlah setelah penyisihan piutang tak tertagih. Selanjutnya pada periode 2016, jumlah piutang yang dilaporkan perusahaan sebesar Rp. 16.275.000,- yang merupakan jumlah setelah penyisihan piutang tak tertagih.

Berdasarkan pembahasan diatas jika dikaitkan dengan standar akuntansi keuangan yang berlaku PSAK No. 55 (revisi 2014) yang menyatakan bahwa aset keuangan diukur nilai wajar bagi yang diakui. Dan PSAK No. 68 (revisi 2015) menyatakan nilai wajar sebagai harga yang akan diterima atau harga yang akan dibaayar. Dimana piutang diukur dalam jumlah yang mewakili nilai sekarang dari perkiraan penerimaan kas dimasa datang dan akuntansi mewajibkan pelaporan piutang sebesar nilai realisasi bersih, hal tersebut dianggap telah sesuai dengan standar akuntansi keuangan yang berlaku karena untuk mengukur nilai aset atau liabilitas diizinkan mengukur atau mengungkapkan berdasarkan nilai wajar dan mewajibkan pelaporan piutang sebesar nilai realisasi bersih. Dengan demikian, dalam hal pengukuran piutang dapat dikatakan bahwa PT. SUCOFINDO (Persero) cabang Jakarta telah mengukur piutang sesuai dengan standar akuntansi keuangan yang berlaku. 


\subsubsection{Analisis Pencatatan Piutang PT. SUCOFINDO (Persero)}

Pada umumnya prosedur pencatatan piutang terdiri dari pengakuan piutang, pencatatan penyisihan piutang, dan penerimaan kembali piutang yang telah dihapuskan. Pencatatan PT. SUCOFINDO (Persero) cabang Jakarta mengguakan basis akrual (accrual basic).

Untuk mencatat pengakuan piutang berdasarkan transaksi pada tanggal 17 Februari 2014 sebesar Rp. 11.500.000,-, pada tanggal 8 Juni 2015 sebesar Rp. 12.000.000,-, dan pada tanggal 1 Maret 2016 sebesar Rp. 10.750.000,- perusahaan mencatat dengan mendebit akun piutang usaha dan mengkredit akun pendapatan.

Selanjutnya untuk mencatat piutang tak tertagih, perusahaan menggunakan metode penyisihan atau cadangan seperti pada akhir periode 2014,dimana jumlah yang disisihkan untuk akhir tahun 2014 sebesar Rp. 6.737.000,-, akhir tahun 2015 sebesar Rp. 5.272.670,-, dan akhir tahun 2016 sebesar Rp. 3.850.000,-. Estimasi ini nantinya akan dicatat pada akhir periode untuk jurnal penyesuaian dengan mendebit akun beban piutang tak tertagih dan mengkredit akun penyisihan piutang tak tertagih.

Hal ini jika dikaitkan dengan Standar Akuntansi Keuangan yang berlaku yaitu PSAK No. 1 (revisi 2015) yang menyatakan bahwa entitas menyusun laporan keuangan atas dasar akrual, kecuali laporan arus kas. Sehingga pencatatan yang dilakukan sebaiknya menggunakan metode akuntansi berbasis akrual. Dan Weygandt, et al (2011) dalam buku Financial Accounting IFRS Edition yang menyatakan bahwa metode penyisihan piutang untuk piutang tak tertagih dilakukan dengan cara mengestimasi jumlah piutang yang tidak tertagih pada akhir periode agar bisa memberikan kesesuaian pembebanan di laporan laba rugi dan memastikan penilaian berdasarkan nilai realisasi kas (bersih) di laporan posisi keuangan (neraca), hal ini dianggap telah sesuai standar akuntansi keuangan yang berlaku karena pencatatan atas dasar akrual diperkenankan oleh Standar Akuntansi Keuangan dan merupakan salah satu metode yang terdapat dalam akuntansi keuangan.

Akan tetapi pada saat terjadinya pembayaran kembali piutang yang telah dihapuskan, perusahaan mencatat piutang sebagai akun pendapatan lain-lain. Hal ini jika dikaitkan dengan standar akuntansi keuangan yang berlaku tentang piutang seperti yang dikemukakan oleh Weygandt, et al (2011) yang menyatakan bahwa ada dua jurnal untuk mencatat penerimaan tagihan dari piutang yang sebelumnya telah dihapuskan yaitu pertama dengan mendebet akun piutang usaha dan mengkredit akun penyisihan piutang tak tertagih untuk menyatakan kembali piutang yang sebelumnya dikeluarkan dari pembukuan. Dan yang kedua dengan mendebet akun kas dan mengkredit akun piutang usaha untuk mencatat penerimaan uang dari penagihan piutang seperti yang pada umumnya dilakukan.

Hal ini dianggap tidak sesuai dengan standar akuntansi keuangan yang berlaku karena perusahaan tidak mengembalikan piutang yang sebelumnya telah dihapuskan. Ketidaksesuaian ini akan mengurangi jumlah aset lancar perusahaan dan laba yang dilaporkan lebih dari yang seharusnya. Jumlah piutang yang seharusnya dilaporkan pada laporan posisi keuangan periode tahun 2014 sebesar Rp. 27.203.000,-, periode tahun 2015 sebesar Rp. 21.286.000,-, dan periode tahun 2016 sebesar Rp. 18.595.000,-. Dengan demikian, di dalam pencatatan piutang dapat dikatakan bahwa PT. SUCOFINDO (Persero) cabang Jakarta tidak mencatat piutang sesuai dengan standar akuntansi keuangan yang berlaku.

\subsubsection{Analisis Penyajian dan Pengungkapan Piutang PT. SUCOFINDO (Persero)}

Piutang merupakan salah satu unsur yang cukup material dari aset lancar sehingga penyajian dan pengungkapannya harus dilakukan secara tepat dan jelas agar tidak menyesatkan para pemakai laporan keuangan. Penyajian dan pengungkapan piutang pada PT. SUCOFINDO (Persero) cabang Jakarta, disajikan dan diungkapkan pada laporan posisi keuangan (neraca) sebagai bagian dari aset lancar dalam jumlah bersih setelah dikurangi 
penyisihan piutang tak tertagih dengan mencantumkan penjelasan didalam laporan posisi keuangan bahwa saldo piutang usaha tersebut adalah jumlah bersih (neto). Piutang yang disajikan dalam laporan posisi keuangan pada periode tahun 2014 sebesar Rp. 23.353.000,-. Kemudian sebesar Rp. 18.506.000 untuk periode tahun 2015,-. Selanjutnya pada periode tahun 2016 sebesar Rp. 16.275.000,-. Jumlah piutang ini merupakan jumlah piutang bersih setelah penyisihan.

Hal ini jika dikaitkan dengan standar akuntansi keuangan yang berlaku tentang piutang yaitu PSAK No. 9 (revisi 2013) yang menyatakan bahwa piutang diklasifikasikan sebagai aktiva lancar. Piutang dinyatakan sebesar jumlah kotor tagihan dikurangi dengan taksiran jumlah yang tidak dapat ditagih. Jumlah kotor piutang harus tetap disajikan pada neraca diikuti dengan penyisihan untuk piutang yang diragukan atau taksiran jumlah yang tidak dapat ditagih, hal ini dianggap tidak sesuai dengan standar akuntansi keuangan yang berlaku karena perusahaan menyajikan piutang dalam jumlah bersih. Ketidaksesuaian ini tidak mempengaruhi jumlah aset yang dilaporkan dalam laporan keuangan. Akan tetapi penyajian pada laporan keuangan menjadi tidak wajar dan tidak sesuai dengan standar akuntansi keuangan piutang yang berlaku.

Begitupun dengan penyajian laporan keuangan perusahaan atas pembayaran kembali piutang yang telah dihapuskan menjadi tidak wajar dan tidak sesuai dengan standar akuntansi keuangan yang berlaku, karena pada saat terjadinya pembayaran kembali piutang yang telah dihapuskan perusahaan mencatat penerimaan sebagai pendapatan lain-lain, yang nantinya akan mengurangi jumlah aset lancar perusahaan dan laba yang dilaporkan lebih dari yang seharusnya. Dengan demikian, di dalam penyajian dan pengungkapan piutang dapat dikatakan bahwa PT. SUCOFINDO (Persero) cabang Jakarta tidak sesuai dengan standar akuntansi keuangan yang berlaku.

\section{KESIMPULAN DAN SARAN}

\subsection{Kesimpulan}

Berdasarkan analisis data yang dilakukan atas hasil penelitian pada PT. SUCOFINDO (Persero) cabang Jakarta, maka dapat disimpulkan bahwa:

1. PT. SUCOFINDO (Persero) cabang Jakarta mengakui piutang setelah jasa selesai diberikan dan telah diterbitkan invoice. Hal tersebut telah sesuai dengan standar akuntansi keuangan yang berlaku yaitu PSAK No. 23 yang menyatakan bahwa pendapatan sehubungan dengan transaksi penjualan jasa harus diakui dengan acuan pada tingkat penyelesaian dari transaksi atas penjualan jasa tersebut.

2. PT. SUCOFINDO (Persero) cabang Jakarta mengukur piutang sebesar nilai wajar atau sebesar jumlah yang dapat direalisasikan dan dapat diterima dalam bentuk kas. Dimana jumlah piutang yang diakui sebesar harga pertukaran (exchange price) atau kesepakatan antara pihak perusahaan dengan pelanggan. Hal tersebut telah sesuai dengan standar akuntansi keuangan yang berlaku yaitu PSAK No. 55 yang menyatakan bahwa pengukuran piutang diakui entitas sebesar nilai wajar. Dan PSAK No. 68 menyatakan nilai wajar sebagai harga yang akan diterima atau nilai pertukaran antara kedua belah pihak pada tanggal transaksi.

3. PT. SUCOFINDO (Persero) cabang Jakarta menggunakan basis akrual (accrual basic) dan mencatat piutang tak tertagih menggunakan metode penyisihan atau cadangan. Hal tersebut telah sesuai dengan standar akuntansi keuangan yang berlaku yaitu PSAK No. 1 yang menyatakan bahwa entitas menyusun laporan keuangan atas dasar akrual, kecuali laporan arus kas. Sehingga pencatatan yang dilakukan sebaiknya menggunakan metode akuntansi berbasis akrual. Dan Weygandt, et al (2011) dalam buku Financial Accounting IFRS Edition yang menyatakan bahwa metode penyisihan piutang untuk piutang tak tertagih dilakukan dengan cara mengestimasi jumlah piutang yang tidak 
tertagih pada akhir periode agar bisa memberikan kesesuaian pembebanan di laporan laba rugi dan memastikan penilaian berdasarkan nilai realisasi kas (bersih) di laporan posisi keuangan (neraca). Sedangkan PT. SUCOFINDO (Persero) cabang Jakarta mencatat piutang sebagai akun pendapatan lain-lain pada saat terjadinya pembayaran kembali piutang yang telah dihapuskan. Hal tersebut tidak sesuai dengan standar akuntansi keuangan yang berlaku seperti yang dikemukakan oleh Weygandt, et al (2011) yang menyatakan bahwa ada dua jurnal untuk mencatat penerimaan tagihan dari piutang yang sebelumnya telah dihapuskan yaitu pertama dengan mendebet akun piutang usaha dan mengkredit akun penyisihan piutang tak tertagih untuk menyatakan kembali piutang yang sebelumnya dikeluarkan dari pembukuan. Dan yang kedua dengan mendebet akun kas dan mengkredit akun piutang usaha untuk mencatat penerimaan uang dari penagihan piutang seperti yang pada umumnya dilakukan.

4. Pada PT. SUCOFINDO (Persero) cabang Jakarta, piutang disajikan dan diungkapkan pada laporan posisi keuangan (neraca) sebagai bagian dari aset lancar dalam jumlah bersih setelah dikurangi penyisihan piutang tak tertagih dengan mencantumkan penjelasan didalam laporan posisi keuangan bahwa saldo piutang usaha tersebut adalah jumlah bersih (neto). Hal tersebut tidak sesuai dengan standar akuntansi keuangan yang berlaku yaitu PSAK No. 9 yang menyatakan bahwa piutang diklasifikasikan sebagai aktiva lancar. Piutang dinyatakan sebesar jumlah kotor tagihan dikurangi dengan taksiran jumlah yang tidak dapat ditagih. Jumlah kotor piutang harus tetap disajikan pada neraca diikuti dengan penyisihan untuk piutang yang diragukan atau taksiran jumlah yang tidak dapat ditagih.

\subsection{Saran}

Berdasarkan hasil penelitian, analisis, dan kesimpulan yang telah ditarik, maka kepada

PT. SUCOFINDO (Persero) cabang Jakarta penulis menyarankan sebagai berikut:

1. Agar pihak perusahaan mencatatan penerimaan pelunasan piutang usaha yang telah dihapusbukukan berdasarkan konsep yang berlaku yaitu dengan mengembalikan kembali piutang yang telah dihapuskan ke dalam akun piutang dan akun penyisihan piutang tak tertagih. Kemudian mencatat penerimaan ke dalam akun kas dan akun piutang sebagai pengurangan atas piutang supaya penyajian laporan keuangan menjadi wajar dan sesuai dengan konsep akuntansi yang berlaku.

2. Agar pihak perusahaan menyajikan piutang sebesar jumlah kotor dikurangi dengan taksiran jumlah yang tidak dapat ditagih. Dimana Jumlah kotor piutang disajikan pada laporan posisi keuangan diikuti dengan taksiran jumlah yang tidak dapat ditagih supaya penyajian piutang sesuai dengan standar akuntansi keuangan yang berlaku.

3. Agar pihak perusahaan selalu konsisten dalam melaksanakan prosedur penerimaan order dengan uang muka 30\% untuk nilai jasa diatas Rp. 10.000.000,- dan pembayaran lunas dimuka sebelum pekerjaan dilaksanakan untuk nilai jasa dibawah Rp. 10.000.000,- dan memberi sangsi kepada pelanggan yang membayar piutang lebih dari jangka waktu yang ditetapkan. Karena cara tersebut adalah cara yang ampuh untuk mengurangi dan menghindari piutang tak tertagih.

4. Agar bagian penagihan selalu konsisten dalam melaksanakan prosedur penagihan piutang dan prosedur evaluasi penagihan piutang sehingga umur piutang di PT. SUCOFINDO (Persero) cabang Jakarta semuanya bisa masuk dalam kategori lancar atau kurang dari 1 tahun. 


\section{DAFTAR PUSTAKA}

Duru, Anastasia Nwakaego, dkk. 2014. Accounts Receivable Management And Corporate Performance Of Companies In The Food \& Beverage Industry: Evidence From Nigeria, Department of Accounting Enugu State University Of Science And Technology Nigeria. In Europea Journal Of Accounting Auditing And Finance Research ( Volume 2 No. 10). Diakses 8 Mei 2017.

Fahmi, Irham. 2013. Analisis Laporan Keuangan. Alfabeta, Bandung.

Fetriyana, 2013. Akuntansi Piutang Usaha Dengan Mengelola Piutang Macet Pada Perusahaan Daerah Air Minum (PDAM) Kota Payakumbuh, Universitas Andalas Padang. Dalam Jurnal Nasional. Diakses 17 Januari 2017.

Gorondutse, Abdullahi Hassan and All, Rahima Abass, 2016. Effect of Trade Receivables and Inventory Management in SMEs Performance, University Utara Malaysia, Kuala Lumpur Malaysia. In British Journal of Economics, Management \& Trade. diakses 8 Mei 2017.

Hati, Shinta Wahyu \& Nababan, Yulia. 2013. Perlakuan Akuntansi Terhadap Piutang Pada Unit Bisnis Infrastruktur PT. PLN Batam, Universitas Politeknik Negeri Batam. Dalam Jurnal Nasional. Diakses 16 Januari 2017.

Ikatan Akuntan Indonesia. 2017. Pernyataan Standar Akuntamsi Keuangan Penyajian Laporan Keuangan PSAK No. 1 (revisi 2015), Jakarta.

Ikatan Akuntan Indonesia. Pernyataan Standar Akuntansi Keuangan Penyajian Aktiva Lancar dan Kewajiban Lancar PSAK No. 9 (revisi 2013), Jakarta.

Ikatan Akuntan Indonesia, 2017. Pernyataan Standar Akuntansi Keuangan Pendapatan PSAK No. 23 (revisi 2014), Jakarta.

Ikatan Akuntan Indonesia, 2017. Pernyataan Standar Akuntansi Keuangan Instrumen Keuangan : Penyajian PSAK No. 50 (revisi 2014), Jakarta.

Ikatan Akuntan Indonesia, 2017. Pernyataan Standar Akuntansi Keuangan Instrumen Keuangan : Pengakuan dan Pengukuran PSAK No. 55 (revisi 2014), Jakarta.

Ikatan Akuntan Indonesia, 2017. Pernyataan Standar Akuntansi Keuangan Instrumen Keuangan : Pengungkapan PSAK No. 60 (revisi 2014), Jakarta.

Ikatan Akuntan Indonesia, 2017. Pernyataan Standar Akuntansi Keuangan Pengukuran Nilai Wajar PSAK No. 68 (revisi 2015), Jakarta.

Jusup, Al Haryono, 2012. Dasar-dasar Akuntansi Jilid 2 (Edisi 7), Universitas Gajah Mada.STIE YKPM, Yogyakarta.

Karina, Ayu Putri, 2016. Analisis Perlakuan Akuntansi Piutang Usaha Pada PT. PLN (Persero) Area Surabaya Selatan. Sekolah Tinggi Ilmu Ekonomi Perbanas, Surabaya. Dalam Jurnal STIE Perbanas surabaya. Diakses 9 Mei 2017.

Kieso, Donald E., Weygandt, Jerry J., Kimmel, Paul D., 2011, Financial Accounting (IFRS ed). New Jearsey: John Wiley \& Sons.

Kieso, Donald E., Weygandt, Jerry J., Warfield, Terry D., 2011, Intermediate Accounting (IFRS ed., Vol 1). New Jearsey: John Wiley \& Sons.

Martani, Dwi. 2012. Akuntansi Keuangan Menengah Berbasis PSAK Jilid 1, Selemba Empat, Jakarta.

Mbula, Kilonzo Jennifer, dkk. 2016. Effect Of Accounts Receivable On Financial Performance Of Firms Funded By Goverment Venture Capital In Kenya, Jomo Kenyatta University Of Agriculture And Finance Vol 7. In IOSR Journal of Economics and Finance (IOSR-JEF) Diakses 8 Mei 2017. 
Mihajlov, Ksenija Dencic. 2012. Impact Of Accounts Receivable Management On The Profitability During The Financial Crisis : Evidence From Serbia, University Of Nis, Faculty Of Economic, Serbia. Diakses 6 Mei 2017.

Novi, 2009. Evaluasi Kebijakan Perlakuan Akuntansi Piutang Usaha Pada PT. CAR PRO, Universitas Katolik Atma Jaya, Jakarta. Dalam jurnal Fakultas Ekonomi Unika Atma Jaya. Diakses 20 Maret 2017.

Octavianty, Ellyn \& Fajarrohim, Ria. 2015. Perlakuan Akuntansi Piutang Air Terhadap Kewajiban Nilai Dan Beban Penyisihan Piutang Pada Laporan Keuangan PDAM Tirta Kahuripan Kabupaten Bogor, Universitas Pakuan Bogor. Dalam Jurnal Ilmiah Akuntansi Fakultas Ekonomi Vol. 1 No. 1. Diakses 16 Januari 2017.

Okpe, Innocent Ikechukwu, 2015. The Effect of Receivable Management on the Profitability of Building Materials/Chemical and Paint Manufacturing Firms In Nigeria, Department of Accountancy Enugu State University of Science and Technology, Nigeria. In Journal of Research in Humanities and Social Sciene Vol. 3. Diakses 8 Mei 2017.

Pontoh, Winston. 2013. Akuntansi: Konsep dan Aplikasi. Halaman Moeka, Jakarta Barat.

Putranto, Andhika Ahi, 2009. Analisis Perlakuan Akuntansi Atas Piutang Usaha Pada PT. Hasuda Graha, Universitas Katolik Atma Jaya, Jakarta. Dalam jurnal Fakultas Ekonomi Unika Atma Jaya. Diakses 20 Maret 2017.

Rahayu, Sri, 2013. Analisis Perlakuan Akuntansi Atas Piutang Dagang Pada Apotek Rakyat Langkat.Universitas Gunadarma, Depok. Dalam Jurnal Gunadarma University. Diakses 9 Mei 2017.

Reeve, M. James, dkk. 2012. Pengantar Akuntansi Adaptasi Indonesia. Buku 2. Selemba Empat, jakarta.

Roosdianto, Muhammad. 2014. Perlakuan Akuntansi Piutang Usaha Pada CV Hana Sejati Group Banjarmasin, Universitas STIE Pancasetia Banjarmasin. Dalam Jurnal KINDAI Vol. 10 No. 3. Diakses 16 Januari 2017.

Rosyafah, Siti \& Pujianto, Wahyu Eko. 2013. Analisis Perlakuan Piutang Usaha Untuk Foreign Exchange Dalam Upaya Foreign Exchange Exposure Serta Dampaknya Terhadap Laporan Keuangan Pada PT. Bintang Tata Bahari Surabaya, Universitas Ubhara Surabaya. Dalam Jurnal NeO-Bis. Diakses16 Januari 2017.

Sugiyono, 2012. Memahami Penelitian Kualitatif. ALFABETA, Bandung.

Susanti, Made Rai, 2008. Perlakuan Akuntansi Piutang Usaha Dan Persediaan Serta Pengaruhnya Terhadap Laporan Keuangan Dan Kinerja Keuangan Pada Koperasi Karyawan Anugrah Dewata. Universitas Udayana Denpasar, Bali. Dalam Jurnal Nasional. Diakses 8 Mei 2017.

Wati, Yeyen Herlina, dkk. 2013. Perlakuan Akuntansi Piutang Dagang (PSAK No. 09) Pada Laporan Keuangan PT. Kebayoran Pharma Samarinda, Universitas 17 Agustus 1945 Samarinda. Dalam Jurnal Fakultas Ekonomi. Diakses 16 Januari 2017.

Wulandari, Desy Dwi. 2013. Perlakuan Akuntansi Atas Piutang Usaha Menggunakan Metode Voucher Pada PT. Para Bathara Surya. Sekolah Tinggi Ekonomi Perbanas, Surabaya. Diakses 20 Maret 2017.

www.Sucofindo.co.id 